\title{
LEGISLATIVE DRAFTING: THE Promulgation of Penal PROVISIONS
}

\author{
Gordon Stewart*
}

The following is an extract from a larger piece of research undertaken for the Law Commission's Drafting Manual project, ${ }^{1}$ one aspect of which deals with the legislative drafting of penal provisions. Within that area specific issues arose such as - Should an offence be created at all? What are the factual elements of the offence? What mental element is appropriate? What defences are to be available? How should the provisions be promulgated (eg, in a statute? in regulations? in rules?)? This article addresses the problems raised by that last issue.

\section{INTRODUCTION}

There are two separate matters to be addressed when considering how a penal provision should be promulgated -

(i) What is the appropriate legislative form?

(ii) Where, within that appropriate legislative form, should the provision be placed?

\section{THE APPROPRIATE LEGISLATIVE FORM}

Regarding the drafting of regulation-making powers, Thornton has commented on: ${ }^{2}$

- Senior Lecturer in Law, Victoria University of Wellington.

1 Part 1, relating to Process, is forthcoming. For Parts 2 and 3, see NZLC R35 - Legislation Manual: Structure and Style. Part 4, relating to drafting issues, is to be published by the Commission in instalments by topic. The author's research related to Part 4 . The views expressed in it are the author's, and do not necessarily reflect the views of the Law Commission.

2 G Thornton Legislative Drafting (3 ed, Butterworths, London, 1987) 274. 
the necessity to get the legislative scheme right; in other words to ensure that matters which ought by reason of their importance or substance to be in principal legislation are not, either with malice aforethought or in blissful ignorance, to be slipped into subsidiary legislation.

Generally, matters of policy or principle deserve to be in the primary legislation - "with regard to major matters the appropriate sphere of delegated authority is where there are no controverted issues of policy or of opinion" ${ }^{\prime 3}$ - and matters of detail or administration in the subordinate legislation. Subject to the difficulties that can arise in distinguishing between those concepts, that approach is by and large followed. It is not, however, impossible to find examples of subordinate legislation being used as the medium for matters which are arguably better suited to primary legislation. These examples can arise because the suggested distinction of roles is too restrictive: ${ }^{4}$

There will be numerous occasions on which the parliament leaves the resolution of policy to its delegate because the nature of the subject matter is such that policy must be formulated on a day to day basis. On occasions, power may be delegated because the parliament has not sorted out the detailed policy that should be pursued. There may be agreement that controls should be exercised but there may be no consensus on the nature of that control. The device is then adopted of leaving it to the executive to determine how the controls are to be exercised.

The Donoughmore Committee (1932), ${ }^{5}$ the first of the major reviews of the practice of delegating legislative powers, accommodated both the general rule and the exceptions to it. The Committee distinguished between "normal" and "exceptional" delegated legislation, "normal" being confined to matters of detail, "exceptional" being made under Acts which conferred powers to legislate on matters of principle, to impose tax, to amend Acts of Parliament, or to exclude the jurisdiction of the courts. ${ }^{6}$ The Committee did not, however, advert to any constitutional principle or working maxim that precludes or discourages the placing of penal provisions in subordinate legislation.

The appropriate legislative medium for penal provisions is that which is most thoroughly debated during its passage and which is most readily accessible to the public after its enactment. Rules and regulations do not readily fit that description. The suggestion that penal provisions might be "hidden" (intentionally or otherwise) in subordinate legislation, ready to spring upon the unsuspecting citizen, is unpalatable. That said, the

3 D C Pearce Delegated Legislation in Australia and New Zealand (Butterworths, Sydney, 1977) 5, citing Freund Administrative Power Over Persons and Property (1928) 218.

4 Pearce, above $\mathrm{n} 3$.

5 Report of the Committee on Ministers' Powers (UK Cmnd 4060).

6 See also Miers \& Page Legislation (2 ed, Sweet \& Maxwell, London, 1990) 109. 
checks and balances which accompany much subordinate legislation should serve to allay many of those fears. Besides, the modern state would function far less efficiently if penal provisions could not be included in subordinate legislation.

From the drafter's point of view, however, there needs to be careful consideration before penal provisions are placed in subordinate legislation. There are a number of issues at play here, but they all have a common thread: subordinate legislation is vulnerable, ${ }^{7}$ both during its passage and after its enactment. The more the content of any particular regulation pushes at the borders of "exceptional" delegated legislation, the greater its vulnerability.

During and after its passage, subordinate legislation is subject to the scrutiny of the Regulations Review Committee. ${ }^{8}$ It is the role of the Committee to decide whether the regulation should be drawn to the attention of the House on any of nine stated grounds.' Those grounds do not include any specific reference to the regulation being penal in nature, but a penal provision could, come within some of the grounds.

Is the regulation in accordance with the general objects and intentions of the statute under which it is made? ${ }^{10}$

Does it trespass unduly on personal rights and liberties? ${ }^{11}$

Does it appear to make some unusual or unexpected use of the powers conferred by the statute under which it is made? ${ }^{12}$

Does it contain matter more appropriate for parliamentary enactment ${ }^{13}$

By design or by chance, regulations are seldom of a nature that the Committee has to take action, but an awareness of the possibility is crucial to the drafter.

After its passage, the regulation is capable of being struck down because it exceeds the scope of the empowering provision under which it was made. Thus in putting a penal provision into a piece of subordinate legislation, care must taken to ensure that (a) the

7 For a comprehensive discussion of subordinate legislation in general, and the issue of its vulnerability in particular, see Pearce, above $n 3$.

8 Standing Orders of the House of Representatives, 1996, S O 195.

$9 \quad$ Above n 8, SO 196.

10 Above n 8, S O 196(2)(a).

11 Above n 8, SO 196(2)(b).

12 Above n 8, SO 196 (2)(c).

13 Above n 8, S O 196(2)(f). 
regulation-making provision in the parent Act permits this, and (b) the regulation which is drafted does not exceed any limits cast upon it by that provision.

The Forests Act 1949 provides a good example of a regulation-making provision which clearly permits penal provisions to be included in regulations -

72 Regulations -

(1) The Governor-General may from time to time, by Order-in-Council, make regulations not inconsistent with this Act for all or any of the following purposes: -

(c) Prescribing offences for the breach of any regulations under this Act ... and prescribing, on summary conviction, -

(i) In the case of an individual, a term of imprisonment not exceeding one month, or a fine not exceeding $\$ 2,000$, and, if the offence is a continuing one, a further fine not exceeding $\$ 200$ for every day during which the offence continues, or to both such imprisonment and fine:

(ii) In the case of a body corporate, a fine not exceeding $\$ 12,000$, and, if the offence is a continuing one, a further fine not exceeding $\$ 1,200$ for every day during which the offence continues.

The Forestry Encouragement Grants Regulations 1983, made under s 72, fall squarely within the scope of s 72: they contain a penal provision (regulation 15) which carries a maximum penalty of $\$ 500$ (for individuals) or $\$ 3000$ (for bodies corporate). ${ }^{14}$

A less clearly stated empowering provision can be found in the (now repealed) Shipping and Seamen Act 1952 -

504 Rules and regulations -

(1) The Governor-General may from time to time, by Order in Council, make all such rules or regulations as may in his opinion be necessary or expedient for giving effect to the provisions of this Act and for the due administration thereof.

The penal regulations passed pursuant to that provision have never been struck down by the courts (nor probably ever challenged), but they sit on less solid ground than those made under $\mathrm{s} 72$ of the Forests Act.

14 Interestingly, the opportunity to provide a custodial penalty in the subordination legislation was clearly declined. This may well have been simply because the offence did not warrant such a response. It may also, however, be indicative of a tacit understanding that, empowering provision notwithstanding, subordinate legislation is not the place for custodial sentences. 
Even where penal regulations are clearly permitted by the parent Act, the drafters of those regulations must not overstep the bounds of that empowering authority. Thus, where a local council was given power to impose penalties not exceeding $£ 10$ for a breach of its by-laws, and where the council passed a by-law dealing with the improper branding of goods, the by-law was held invalid because, in addition to the penalty for the breach of the by-law, it also provided for the goods to be forfeited: that was a penalty upon a penalty and not permitted by the empowering Act. ${ }^{15}$

Similarly, where an Act provided for unpaid taxi fares to be recoverable in court, and where the ensuing regulation provided that the court could order repayment of the fare together with compensation for loss of the plaintiff's time, the regulation was held invalid because the Act did not allow orders for compensation. ${ }^{16}$

[These cases] are really examples of regulations being ultra vires the empowering Act in the sense that an attempt was being made to exercise the regulation-making power for a purpose for which no authority was given. But the cases do show that the general attitude of the courts will be that penalties and forfeitures may only be imposed when permitted by the empowering Act and then must accord with the provisions of the Act. ${ }^{17}$

The drafters of those regulations erred - no doubt unintentionally - in attempting to provide in the regulations a form of penalty (forfeiture; compensation for loss of time) not envisaged or permitted by the empowering Act. There is, however, also the danger of providing penalties in the form envisaged by the Act, yet still overstepping the mark. The most obvious is the clear breach of limits: that is, the Act permits regulations imposing maximum penalties of $\$ 100$, but the regulation imposes a penalty of a sum exceeding that. The maximum can be exceeded less blatantly however. Thus, where power was given to make by-laws and to impose a maximum penalty of $£ 20$ for any breach of those by-laws, a by-law which prohibited persons from using a vehicle for commercial purposes without having a licence to do so, and which imposed a penalty of not less than $£ 1$ and not more than $£ 5$ for every day on which the vehicle was so used, was held to be invalid. The offence in the by-law was a single offence, not a continuing one, but the penalty in the by-laws was inconsistent with that and could, contrary to the authority in the empowering Act, exceed $£ 20 .^{18}$

15 In Re the Corporation of the City of Port Adelaide; Ex parte Groom [1922] SASR 35; discussed in D C Pearce Delegated Legislation in Australia and New Zealand (Butterworths, Sydney, 1977) 158.

16 Bishop v MacFarlane (1909) 9 CLR 370, discussed in Pearce, above n 15.

17 D C Pearce, above n 15.

18 Metropolitan Transit Commissioners v Berry; Ex parte Berry (1899) 9 QLJR 117, discussed in D C Pearce, above $\mathbf{n} 15$. 
Care must be taken, when placing penal provisions in subordinate legislation, to ensure that there is no duplication with the empowering Act. For example, s 197 of the Shipping and Seamen Act 1952, required the owners of every New Zealand ship to have that ship surveyed at least once in each year, and the Act provided that a failure to comply with that requirement was an offence against the Act. ${ }^{19}$ The penalty for the offence was in $\mathrm{s} 480$ -

(2) Every person who commits an offence against this Act for which no penalty is provided elsewhere than in this section shall be liable in respect of each offence to a fine not exceeding $\$ 1,000$.

(3) Where an offence against this Act is a continuing one, and no penalty is provided in respect of the continuance thereof elsewhere than in this section, every person who commits that offence shall, in addition to any other liability, be liable to fine not exceeding $\$ 50$ for every day or part of a day during which the offence continues.

Regulation 6 of the Shipping (Survey) Regulations 1989 - made pursuant to the 1952 Act - required the owners of every ship to which the regulations applied (and that included New Zealand ships) to have that ship surveyed once in each year, and failure to comply with that regulation was an offence, carrying a penalty of a fine not exceeding $\$ 1,000$, plus, if the offence was a continuing one, $\$ 100$ for every day on which it continued. ${ }^{20}$

Which provisions - and which penalties - prevail? ${ }^{21}$ It is unlikely that the owner would be liable, in respect of the same act or omission on his/her part, for both the s 480 penalty (for breach of s 197) and the reg 29 penalty (for breach of reg 6), but the question remained about which provision would be the focus of contemplated proceedings.

Finally, the related point of the level of penalties that can appropriately be imposed by the various forms deserves attention. Any suspicion that the higher level penalties are to be found in statutes, and lower levels in regulations, is not borne out in practice. Across the statutes, there is an wide range of penalties, from fines of $\$ 2^{22}$ to fines of $\$ 5$ million, ${ }^{23}$ from

19 Section 197(2).

20 Regulation 29.

21 Certainly s 480 does say that it only applies to offences against the Act for which no penalty is provided elsewhere than in $s \mathbf{4 8 0}$, and it could be argued that there is a penalty elsewhere, namely reg 29 . However, the penalty in reg 29 is for an offence against reg 6 , not for an offence against s 197. If so, then the penalty stipulated in s 480 is the only one for the breach of s 197 .

22 Companies Act 1955, s 147(6) (now amended). In practice, the fine was likely to be higher. Section 147 deals with a company's duty to distribute copies of resolutions. The figure of $\$ 2$ was the fine for each copy in respect of which default was made. In 1993, the penalty was amended to a simple fine of $\$ 5000$, regardless of the number of copies in respect of which default was made. However, there are other instances of low level fines on the statute books: $\$ 4$ (Shipping and Seamen Act 1952, s 164(1)(b) - although the defendant was also liable to forfeit up to 2 days' 
custodial sentences of 2 days $^{24}$ to mandatory life imprisonment. ${ }^{25}$ The range of penalties across regulations is less easy to determine, but large fines are not unknown there. One set of regulations, for instance, imposed a fine of $\$ 100,000$ for a breach of its provisions. ${ }^{26}$ Custodial penalties are less readily apparent in the regulations. ${ }^{27}$

It is impracticable to simply suggest that penalties (whether fines or custodial sentences) of the higher levels should be placed in the statutes, and lower level penalties in the regulations. The level of penalty depends on the act or omission to which it relates. The more grave acts and omissions should themselves be in the statutes, and the less grave in the regulations - a situation that would reflect the idea that important matters of principle should be in primary legislation, and matters of detail in the subordinate.

Penalties of another nature, such as forfeiture of goods or suspensions or loss of operating licences, are less easy to place. It is often appropriate that they appear in the regulations, since the details relevant to the grant of a licence will also be in those regulations. However, the loss of a licence can have an effect similar to, or even greater than, the imposition of a fine, and, therefore - if the basic distinction between the roles of primary and secondary legislation is observed - ought to be stated in the statute.

The issue could be resolved by a requirement that all statutes, and particularly those under which regulations containing offences and penalties are likely to be passed, must specify the type, and maximum level ${ }^{28}$ of any penalties that may be imposed.

wages); $\$ 10$ (Auctioneers Act 1928, s 39).

23 Commerce Act 1986, s 83(1).

24 Shipping and Seamen Act 1952, s 164(2)(b).

25 Crimes Act 1961, s 172.

26 Exclusive Economic Zone (Interim Measures for Foreign Fishing Craft) Regulations 1977, reg 5(2) (now repealed).

27 For an unusual example of custodial sentences introduced by regulation, see the Tokelau Crimes Regulations 1975, which made applicable in Tokelau certain parts of the Niue Act 1966, some of which impose custodial sentences for offences.

28 "Maximum level" need not be a set figure. Indeed, that would be impossible for those penalties which are linked to the commercial gain which a defendant made because of the breach. "Maximum level", then, could include guidelines, such as "... pay an amount not exceeding 3 times the value of any commercial gain resulting from the commission of that offence if the Court is satisfied that the offence was committed in the course of producing a commercial gain". (Maritime Transport (No 2) Bill 1993, cl 407.) 


\section{WHERE SHOULD THE PROVISION BE PLACED?}

Where, within the appropriate legislative form, should the main elements of a penal provision be placed? The short answer is, "together".

The "main elements" of the provision are - "offence, conduct, and penalty". 29 That is to say, the text of the provision should make clear (as a minimum)

(1) that if certain conduct occurs,

(2) an offence will have been committed, and

(3) the penalty to which the offender is liable. For example: ${ }^{30}$

Every person (unless authorised by this Act) commits an offence, and is liable to a fine not exceeding $\$ 5,000$, who takes, removes, disturbs, or interferes with any fish, aquatic life, or seaweed being farmed in an area in respect of which a marine farming permit has been issued under section 67J of this Act.

Any other practice results in a legislative dislocation, which is at best annoying, at worst dangerous, and nearly always unnecessary. This dislocation occurs whenever one or more of those elements is separated in the legislation from one or more of the others.

\section{A Dislocation of conduct and offence elements}

Sections 15 and 61 of the Maritime Transport Act 1994 read ${ }^{31}$

15 Duties of employers in respect of persons who are not seafarers -

Every employer of seafarers on a New Zealand ship shall take all practicable steps to ensure that no action or inaction of any seafarer while on the ship harms any other person.

\section{Other offences -}

(1) Every person commits an offence who fails to comply with -

(a) Any provision of Part II of this Act (other than section 14);

Here, certain conduct is required, and a failure to fulfil that requirement constitutes an offence, but that link is not made clear at the place at which the conduct is set out. Readers should be clear about when they might be committing an offence, but an employer reading

29 See G Thornton Legislative Drafting (3 ed, Butterworths, London 1987) 291.

30 Fisheries Act 1983, s 101A(1).

31 Section 15 is in Part II of the Act. 
s 15 would not immediately (and maybe not until too late) realise that a breach of that duty is an offence punishable by a fine of up to $\$ 50,000 .^{32}$ Furthermore, employers may more readily satisfy the requirements of $s 15$ if they know that a failure to do so constitutes an offence.

Contrast s 105 of the same Act -

105 Rules to be observed by person finding wreck -

(1) Where any person finds or takes possession of any wreck within the limits of New Zealand, or takes possession of and brings within the limits of New Zealand any wreck found outside those limits, he or she shall -

(a) If he or she is the owner thereof, give notice to the appropriate Receiver, stating that he or she has found or taken possession of the wreck, and describing the marks by which the same may be recognised:

(b) If he or she is not the owner thereof, as soon as possible deliver the same to the appropriate Receiver.

$\cdots$

(3) Every person who fails without reasonable cause to comply with this section commits an offence, ...

Section 105 links conduct and offence; it clearly indicates that certain conduct constitutes an offence, and it does so without requiring the reader to refer elsewhere in the statute.

Requiring the reader to cross-refer is not, however, the only problem raised by the dislocation of conduct and offence elements. Of greater concern is the danger that, by separating the conduct and the offence elements, the drafter unintentionally creates offences, and the wider the net that is cast by the offence element - which sits in a provision by itself the greater is the risk of this occurring. ${ }^{33}$ For example, unlike s 61 of the Maritime Transport Act which only casts a net over anyone "who fails to comply with ... any provision of Part II of this Act", an ambitious s 93 of the Fisheries Act 1983 reads -

32 Maritime Transport Act 1994, s 62(2).

33 Above n 2, 293. 


\section{General offences -}

Every person commits an offence who acts in contravention of or fails to comply with any provision of this Act, or any notice, direction, restriction, requirement, or condition given, made, or imposed under this Act.

The potential scope of that is well illustrated by reference to s 9 of the same Act. That section lays down a procedure by which certain affected people may. object to any proposed fishery management plan, $\mathrm{s} 9(2)$ reads -

Every objection shall identify the provisions of the plan objected to, the grounds and the relief sought, and shall be supplemented by such particulars and information as the DirectorGeneral notifies the applicant he considers necessary to sufficiently identify the grounds of the objection.

By force of $s 93$, it seems that if an objection fails to satisfy each of the requirements in $s$ $9(2)$, the objector has committed an offence. This is a worrying prospect. The penalty ${ }^{34}$ for "an offence against this Act ... for which no other penalty is prescribed" is "a fine not exceeding $\$ 250,000$, and, if the offence is a continuing one, ... a further fine not exceeding $\$ 1,000$ for every day after the first day on which the offence has continued. ${ }^{135}$ No "other penalty is prescribed" elsewhere in the Act: it is unlikely that the drafter realised that the combined effect of ss $9(2)$ and 93 was the creation of this specific offence. ${ }^{36}$

\section{B Dislocation of offence and penalty elements}

Clause 105 of the Maritime Transport (No 2) Bill, which in itself combined the conduct and offence elements, and cl 126A of that Bill provide a good example. Clause 126A read -

(2) Every person who commits an offence against section 105 or section 106 of this Act is liable to a fine not exceeding $\$ 5,000$ and, if the offence is continuing one, to a further fine not exceeding $\$ 250$ for every day or part of a day during which the offence is continued.

A person is required to discover, and then cross-refer to another section before being aware of, let alone clear about, the punishment to which their behaviour has exposed them. The harshness of this would be reduced if $\mathrm{cl} 105$ had indicated that penalties for its breach lay in cl 126A.

34 The penalty is in a provision dislocated from both the conduct and the offence elements (s 107).

35 Fisheries Act 1983, s 107.

36 A possible solution to the problem illustrated by $\mathrm{s} 93$, appeared in the wording of cl 62(1)(b) of the Maritime Transport (No 2) Bill. It read, "Every person commits an offence who fails to comply with any provision of any regulations made under this Act declared by those regulations to be a provision to which this section applies". (Clause 62(1)(b) did not reappear in s 62(1) of the Maritime Transport Act 1994). 
The dislocation of the penalty element from the offence element can also lead to unintentional omissions. For example, in several clauses of the Maritime Transport Bill (No 2) certain conduct was declared to constitute an offence, but no penalty was provided in those clauses; the question of penalties was held over to be dealt with in one fell swoop in a later clause.

There is some attraction in this, particularly if a large number of offence clauses have a common penalty; it saves space and time to simply state the penalty once, in a provision that refers to all the relevant offence provisions. ${ }^{37}$ Clause 184 of the Maritime Transport Bill (No 2) was a good example of this approach -

\section{Penalties -}

(1) Every person who commits an offence against any of sections 130, 131, 150, and 170 of this Act shall be liable to a fine not exceeding $\$ 5,000$ and, if the offence is a continuing one, to a further fine not exceeding $\$ 250$ for every day or part of a day during which the offence is continued.

(2) Every person who commits an offence against any of sections 132, 135, 143, 154, 160, and 172 of this Act is liable, -

(a) In the case of an individual, to imprisonment for a term not exceeding 12 months or a fine not exceeding $\$ 10,000$ :

(b) In the case of a body corporate, to a fine not exceeding $\$ 100,000$.

(3) Every person who commits an offence against any of sections 146, 148, 163, 169(3), $171(2), 173(5), 174(3), 175(3), 177,179(5), 180,182$, and 183 of this Act is liable, -

(a) In the case of an individual, to imprisonment for a term not exceeding 12 months or a fine not exceeding $\$ 5,000$ :

(b) In the case of a body corporate, to a fine not exceeding $\$ 30,000$.

This technique demands, however, that the drafter records and covers each and every earlier offence provision when drafting the later compendious penalty provision. Accuracy is vital. The greater the number of offence provisions to which the penalty provision must refer, the greater the risk of a slip. The Maritime Transport Bill (No 2) made such a slip: $\mathrm{cl}$ 184 , in its attempt to cover 24 earlier offence provisions, covered only 23 of them. As it stood, the Bill was on track to becoming a piece of legislation which would contain an offence provision - s169(4) - for which no penalty was provided. ${ }^{38}$ This is a risk which

37 Above n 2, 292. Again, however, the harshness would be reduced if the separate offence provisions each contained a reference to the compendious penalty provision. 
does not exist if the drafter opts instead to cover the conduct, the offence and the penalty elements in the same provision.

Even if the omnibus penalty provision does accurately refer to all the offence provisions over which it is to have effect, the danger of omission persists. On each occasion that the penalty provision or the offence provisions are amended, there is the danger of the related provision not being appropriately amended at the same time. Legislation which originally used the "one penalty provision for several discrete offence provisions" approach, has the potential, in the course of amendments, to fall into the trap of containing an offence for which there is no penalty, or vice versa.

In addition to those practical problems, the use of one penalty provision to cover several separate offence provisions can encourage drafters to spend less time ensuring that the penalty fits the crime, relying instead on a type of "one size fits all" approach to fixing penalties. It may be that, when the legislation is first passed, that is indeed the case as regards several separate offences and their appropriate penalties. However, subsequent amendments to the particulars of the offence provisions demand that attention be paid to whether or not the penalty remains appropriate, and if the penalty is dislocated from the offence there is a possibility that that reference might not occur. Although the chances of missing any such cross-references should be reduced by the increasing use of computer databases of statutes, they will never be entirely eliminated - except by having the offence and penalty elements together in the same provision.

The examples of dislocation discussed above, while annoying or dangerous, at least occurred within the same statute. The annoyance, and of course the danger, increases when the dislocation occurs across statutes. If it is accepted that no person should be exposed to the likelihood of having committed a criminal offence without having been given fair and readily accessible statutory warning of that offence, then more complicated versions of the dislocation paradigm are totally unacceptable. For example, the Commercial Use of Royal Photographs Rules 1955, which covers the use of photographs of members of the Royal Family in the design of articles for sale, has, the following provisions -

5 Permission to use a royal photograph in the design does not extend to:

(a) Articles of dress, except scarves and headsquares:

6 For the present, ${ }^{39}$ photographs of The Duke of Cornwall and The Princess Anne may not be used, except that they may be sold as portraits or as postcards, and be reproduced on calendars. 
The Crimes Act 1961 makes it an imprisonable offence to contravene any enactment by wilfully doing any act which it forbids, or by wilfully omitting to do any act which it requires, ${ }^{40}$ and the Acts Interpretation Act 1924 states that "Act" (which presumably is an "enactment") includes rules and regulations made under any Act of the General Assembly. ${ }^{41}$ Is it possible, then, that an entrepreneur who sells T-shirts emblazoned with large photographs of Princess Anne, has contravened an enactment and made him or herself liable to one year's imprisonment? If so, it is unlikely that they would have had any inkling of that possibility: the provisions which spelled out the conduct, the offence and the penalty are severely dislocated across two statutes and one set of rules - none of which bear, for the casual reader, any immediately apparent relation to each other. ${ }^{42}$

\section{CONCLUSION}

When drafting penal provisions, careful thought needs to be given to the manner in which they are enacted. While the logical starting point is the general approach of reserving statutes for matters of important policy and/or principle, and subordinate legislation for matters of detail, penal provisions can be frustratingly difficult to categorise along those lines. In one respect, they are matters of detail which serve to elaborate upon a more general policy or principle, and therefore belong in regulations. However, some penal provisions can be of such weight that to consign them to subordinate legislation borders on the

their working life-span is given.

40 Crimes Act 1961, s 107. There is a possible argument that part of the proviso to s 107 applies: a person is not liable to imprisonment if "in the case of any such contravention ... it is ... inconsistent with the intent and object of the enactment, or with its context, that the contravention should be regarded as an offence". There is also the question of whether the 1955 Rules "forbid" certain uses of royal photographs, or whether they simply indicate those uses for which the Queen has given her permission. It is doubtful whether $\mathrm{s} 107$ has ever been used - for the Commercial Use of Royal Photographs Rules or in any other context - but for a very brief discussion of its predecessor (Crimes Act 1908, s 129) see Pease E Ors v Eltham Borough [1962] NZLR 437.

41 The Acts Interpretation Act 1924, s 4. See also The King $v$ Seager [1941] SCR 111, and Japanese Reference [1947] AC 87, both discussed in E A Driedger "Subordinate Legislation" (1960) 38 Can Bar Review 1.

42 This must be distinguished from cross-referencing between enactments that are related and where such cross-referencing is both expected and accepted. For example, s 38(1) of the Maritime Transport Act 1994 reads, "Every person commits an offence who, without reasonable cause, acts in contravention of or fails to comply with any emergency maritime rule made under section 37 of this Act". This is an acceptable practice. The provision notifying the public of the offence is in the Act, where it belongs, rather than hidden in subordinate legislation, and the specific details of the conduct that makes up the offence are in related and clearly identified rules. There is, or course, still the danger that the rather broad terms of $\mathrm{s} 38$ expose it to the same criticism that was levelled at $\mathrm{s} 93$ of the Fisheries Act, ie is it so wide that it might catch activity which was not intended to constitute an offence? That danger can be dealt with by more careful drafting, such as that in cl 62(1)(b) of the Maritime Transport (No 2) Bill: see above $n 36$. 
unconstitutional: it fails to make them readily available to the affected public, both during their passage when the public may wish to make submissions on them, and during their later life on the legislation books. When deciding the appropriate form for promulgation, each penal provision deserves separate and full attention.

Once the appropriate form of legislation has been selected, it is submitted that, unless there are good reasons to the contrary, the main elements of the provision - ie the proclamation of the offence, the conduct that constitutes the offence, and the penalty - should appear in the same section, clause or rule. If the elements are to be dislocated in any way, consideration should be given to including in each of the separate provisions a subsection or explanatory footnote which directs the reader to the related provision. To fail to do so can lead to legislation which is difficult to follow and to a denial of basic principles of access to justice. 